\title{
Zbigniew Malara
}

Politechnika Wrocławska

Katedra Infrastruktury Zarządzania

e-mail: zbigniew.malara@pwr.edu.pl

\section{Technologie IT na usługach przedsiębiorstwa wieku globalizacji}

Kod JEL: M15

Slowa kluczowe: gospodarka w sieci, przedsiębiorstwo wieku globalizacji, technologie IT

Streszczenie. W artykule zawarto zapis wyzwań wieku globalizacji przed jakimi stają współczesne przedsiębiorstwa i sposobów ich mitygowania $\mathrm{z}$ uwzględnieniem technologii teleinformatycznych (IT). Sposoby rozwiązywania problemów omówiono z uwzględnieniem aktywności przedsiębiorstw we wszystkich ogniwach łańcucha wartości.

\section{Wprowadzenie}

Przenikanie technologii informatycznych do życia przedsiębiorstwa okresu globalizacji tworzy nowe jakości, nowe formy i nowe kategorie odnoszone do jego działalności. Zmianom podlegają zarówno struktury wewnętrzne przedsiębiorstwa, jak i zasady jego funkcjonowania. Spektakularnym przejawem zmian w obrębie struktury wewnętrznej jest jej wirtualizacja, co w skali globalnej wywołuje zjawisko tzw. cyberprzestrzeni, czyli rzeczywistości wirtualnej. Dla przedsiębiorstwa oznacza to odmianę charakteru kontaktów pomiędzy uczestnikami procesu biznesowego. Nie jest to bowiem, wyłącznie tradycyjny kontakt przedsiębiorstwo-klient, lecz kontakt elektroniczny lub wirtualny.

\section{Gospodarka w sieci}

Określenie gospodarka elektroniczna jest pojęciem bardzo pojemnym, odnosi się bowiem do rozmaitych form nośników i urządzeń elektronicznych, takich jak faks, 
elektroniczna poczta, elektroniczna wymiana dokumentów, w szczególności zaś, odnosi się do transakcji zawieranych poprzez internet (można wtedy mówić o gospodarce internetowej) ${ }^{1}$.

O ocenie skali rozprzestrzeniania zjawiska się jakim jest internet decyduje wiele czynników, a za najbardziej znaczące można uznać następujące z nich:

1. Filozofia połączeń i dostęp do sieci jej użytkowników, oparty na logice wystandaryzowanych i nieustannych połączeń, a to oznacza - zdaniem F. Cairncrossa (1997) - „koniec fizycznych odległości”.

2. Szybkość połączeń - internet daje możliwość natychmiastowego łączenia się i komunikowania wszystkich ze wszystkimi w czasie rzeczywistym (real time), co pozwala na podejmowanie rozmaitych decyzji służących operatywnemu zarządzaniu, na przykład koordynacji łańcuchów zaopatrzenia, produkcji i sprzedaży na potrzeby globalnego rynku.

3. Koszt połączeń - połączenia $\mathrm{z}$ wykorzystaniem internetu są, w relacji do klasycznych sposobów komunikowania się, tanie. Szczególnie początek trzeciego tysiąclecia pokazał dalszy, znaczny spadek kosztów dostępu do sieci internet. Wynika to między innymi z powiększania się liczby użytkowników (klientów) sieci oraz dramatycznej obniżki cen infrastruktury techniczne (głównie serwerów).

4. Zasięg połączeń oraz wielkość i dynamika rozwoju sieci - internet to zjawisko globalne i rozwojowe. Wskazuje na to zarówno rosnąca wykładniczo liczba użytkowników z dostępem do sieci, jak i liczba przedsiębiorstw posiadających komercyjne strony WWW, a także liczba tych stron oraz lokalizacja podłączeń do sieci ${ }^{2}$.

5. Procesy biznesowe w sieci - internet dynamizuje również procesy konkurencji. Posługując się metaforą, można sformułować pogląd, że sytuacja konkurencji na rynku sprzed okresu internetu przypominała wyścig, w którym konkurenci biegli po niezależnych, własnych torach, zgodnie z indywidualnym rytmem. Internet spowodował, że obecnie walka konkurencyjna o prymat na rynku przypomina bieg masowy ze wspólnego startu, gdzie tory biegu przebiegają często po kolizyjnych kursach, tempo jest zmienne, a konkurowanie wymaga roztropności oraz szybkiego reagowania na ujawniające się sytuacje.

1 Firma Andersen Consulting - przedsiębiorstwo o ustalonej renomie na globalnym rynku posługuje się definicją, według której „gospodarka elektroniczna, to sposób prowadzenia działalności gospodarczej poprzez uniwersalne powszechne sieci komputerowe" (Kaku, 2000, s. 55).

2 Przedsiębiorstwo Consultingowe NUA Internet Surveys szacuje, że spośród wszystkich przedsiębiorstw na świecie, użytkujących komputery w ponad 100 krajach, ok. $70 \%$ z nich posiada dostęp do internetu, a 15\% - własne strony WWW, głównie w Stanach Zjednoczonych i Kanadzie (60\%) oraz w Europie i Australii (30\%). Reszta przypada krajom afrykańskim i Bliskiego Wschodu., przy czym ocenia się, że łączna liczba informacji w sieci intranet ulega podwojeniu każdego roku (za: Szapiro, Ciemniak, 1999, s. 44). 
Sieć internet zapewnia (oferuje) wiele usług sieciowych, z których korzystają jej użytkownicy (klienci), począwszy od zwykłej wymiany korespondencji między dwoma partnerami, aż po skomplikowane usługi związane z wyszukiwaniem i transferem wiedzy w sposób ciągły między wieloma użytkownikami sieci. Są to: wymiana poczty elektronicznej (Electronic Mail), umożliwiająca prowadzenie korespondencji między użytkownikami sieci; transfer plików oraz zdalne korzystanie z komputera dzięki usłudze FTP (File Transfer Protocol); grupy dyskusyjne, korzystając z możliwości uczestnictwa w nich, użytkownik może czerpać z gromadzonej wewnątrz grupy wiedzy, sięgając po interesujące go informacje, usystematyzowane wedle kwerend (sprecyzowanych kryteriów), a także umieszczać tam swoje informacje celem udostępniania ich innym użytkownikom sieci (uczestnikom grupy); systemy komunikacyjne oparte na dwóch kluczowych usługach komunikacji (systemy obsługi) oraz system IRC (Internet Relay Chat) oraz tzw. internetowe kawiarenki (Chat Rooms), a także dostęp do informacji i możliwość korzystania z zasobów sieci poprzez możliwości tworzone przez World Web Wide (strony WWW).

Z punktu widzenia użytkowników sieci internet oferowane przez sieć usługi oraz ich rozwój, sprzyjają ewolucji internetu w kierunku coraz bardziej masowego zjawiska, jakim jest gospodarka wirtualna.

\section{Przedsiębiorstwo w sieci}

Za sprawą internetu utrwala się zjawisko powstawania tzw. społeczności wirtualnych. Społeczności te, ich sposób zorganizowania oraz filozofia funkcjonowania, stanowią o poziomie reprezentacji przez nie interesów swoich członków wobec producentów i sprzedawców produktów oraz usług oferowanych w sieci internet, niezależnie od czasu i miejsca, tzn. kiedy i gdzie się aktualnie znajdują ich przedstawiciele.

Zjawisko to wydaje się w pełni zgodne z koncepcją nowej ekonomii, pojemnego pojęcia (Information Economy, Knowledge Driven Economy, Network Economy), która uwzględnia odmienne niż działo się to w tradycyjnej gospodarce role i znaczenie produktu, usług oraz ich wzajemnych relacji ${ }^{3}$.

Czynnikiem aktywizującym powstawanie społeczności wirtualnych są tzw. pośrednicy, czyli operatorzy (dostawcy usług internetowych), będący równocześnie reprezentantami tych społeczności wobec otoczenia. Naturalną konsekwencją jest, że powstały układ tworzy warunki sprzyjające do czerpania zysków przez operatorów, którzy są w stanie zaoferować swoim kontrahentom (sprzedawcom produktów i usług) bezpośredni dostęp do skoncentrowanej w wirtualnej przestrzeni grupy klientów o określonych cechach (wymaganiach, potrzebach, zainteresowaniach itd.). Tym samym, sprzedawca (producent) będzie mógł po konkurencyjnych cenach (niższych niż pozostali

3 ,We are rapidly moving a trust economy, that has progressed through three eras: Product, Service and Relationship" (Keen, Ballance, Chan, Schrump, 1999, s. 11). 
uczestnicy transakcji) przeznaczyć swoją ofertę (produkt lub usługę) takiej grupie klientów.

Z uwagi na większe możliwości uzyskania informacji zwrotnej od klientów oraz bogatszej informacji o rynkach, efekty działalności marketingowej oferentów są lepiej widoczne i bardziej skuteczne. Członkowie społeczności wirtualnej (klienci) zaś, ze względu na wysoki stopień koncentracji, dysponują znaczącą siłą przetargową (lobbing) wobec sprzedawców, uzyskując dzięki temu korzystniejsze warunki zakupów, a to oznacza, między innymi, niższą cenę czy wyższą jakość. Ponadto, logika i sposób zorganizowania internetu umożliwiają bezpośredni dostęp do informacji i dokonywanie porównań i oceny ofert. Maleje więc asymetria w wiedzy o produktach i usługach pomiędzy oferentami (dostawcami) a klientami (odbiorcami) sieci, która w tradycyjnej gospodarce stawiała dostawców na pozycji uprzywilejowanej. Mogli oni niemal dowolnie formować postać informacji, które przekazywali nabywcy. Czynili to wedle intencji, które im przyświecały oraz celów, jakim miały one służyć, zatajając przy tym dużą część informacji istotnych dla nabywcy.

Wskutek wpływu na sposób kształtowania się cen rynku, procesy transakcji zawieranych $\mathrm{w}$ wirtualnej społeczności mogą prowadzić do zwiększenia tzw. ekonomicznej nadwyżki klienta. Proces odwracania rynku polega wtedy na tym, że klienci zgłaszają swoje wymagania, a dostawcy (producenci, sprzedawcy) uczestniczą w przetargu, którego celem jest upłynnienie swoich ofert po najkorzystniejszych dla stron transakcji cenach. Wskutek tego powstają swoiste subrynki złożone z klientów społeczności wirtualnej, którzy uznają propozycje tych oferentów, których produkty i usługi osiągają najniższe ceny, ewentualnie wnoszą wyższą wartość dodaną.

\section{Obszary wirtualnej aktywności przedsiębiorstwa}

Wpływ internetu, zaznaczony głębokimi zmianami we wszystkich obszarach gospodarki, w których instrument ten znajduje coraz wyraźniejsze zastosowanie, można dostrzec zarówno w samym przedsiębiorstwie, jak i w jego otoczeniu bliższym i dalszym. Z jednej strony internet wpływa na szybkość kreowania nowych technologii, zmienia reguły ekonomiczne i wyznacza odmienną od dotychczasowej jakość więzi społecznych i wymusza nowe regulacje prawne. $Z$ drugiej zaś, powoduje, że otoczenie przedsiębiorstwa - świat dostawców i klientów, dystrybutorów i konkurentów oraz podmiotów instytucjonalnych zmienia intensywność i charakter działań względem uczestników rynku oraz siebie samych. W samym przedsiębiorstwie zaś, internet powoduje przymus redefiniowania sposobów wewnętrznej komunikacji oraz otwierają się nowe przestrzenie służące komunikacji z otoczeniem. Wszystko to sprawia, że lista możliwości, które stają przed przedsiębiorstwem $\mathrm{w}$ formie wirtualnych przestrzeni rynkowych rośnie, a sam internet nabiera cech ważnego instrumentu w budowie pozycji konkurencyjnej przedsiębiorstwa na globalnym rynku. 
Wyróżnianie tego instrumentu nie jest pozbawione podstaw, bowiem jego rola w przedsiębiorstwie nie ogranicza się wyłącznie do wzbogacania instrumentarium w sensie rzeczowym, lecz trzeba mu przypisać kapitalne znaczenie również w sensie jakościowym i to w szerokim znaczeniu tego pojęcia.

Jak wspomniano wcześniej, internet kreuje odmienne od tradycyjnych, wirtualne przestrzenie rynkowe, tworząc swoiste segmenty złożone $\mathrm{z}$ nowych obszarów, w których przedsiębiorstwa zawierając między sobą transakcje, mogą wymieniać informacje, komunikować się, prowadzić dystrybucję produktów i usług oraz zawiązywać transakcje handlowe:

1. Wirtualną przestrzeń informacji tworzą nowe kanały informacji, którymi przedsiębiorstwo może udostępniać informacje o sobie i o swoich produktach. Tą drogą może ono upowszechniać, między innymi, katalogi wyrobów oraz zbierać opinie swoich klientów, a także poszerzać zasoby wiedzy o rynku.

2. Wirtualna przestrzeń komunikacji to nowy obszar służący wymianie poglądów i idei inspirujących innowacyjne rozwiązania, i gdzie kształtują się opinie, gdzie wreszcie odbywają się negocjacje oraz zawiązuje współpraca między uczestnikami rynku. Sprzyja temu uzyskiwanie szybkich i tanich połączeń w sieci, które wzmacniają możliwości budowania i kształtowania ich wzajemnych relacji.

3. Wirtualna przestrzeń dystrybucji kreuje kanały dystrybucji towarów i usług. Odnosi się to zwłaszcza do tych produktów, które mogą być zapisane w formie cyfrowej, a informacje o nich mogą być upowszechniane z wykorzystaniem sieci internet ${ }^{4}$.

4. Wirtualna przestrzeń transakcji wiąże się $\mathrm{z}$ wykorzystywaniem kanałów w sieci internet do zawierania formalnych transakcji handlowych (np. zamówienia, rachunki i faktury oraz płatności).

Wynika z tego, że wirtualną przestrzeń działalności przedsiębiorstwa determinują cztery jej główne składowe - wirtualne przestrzenie: informacji, komunikacji, dystrybucji i transakcji, na podstawie których przedsiębiorstwo jest w stanie formułować rozwiązania wykorzystujące możliwości drzemiące w otoczeniu i związane z internetem, a ponadto - identyfikować potencjalne zagrożenia wywołane tym zjawiskiem.

4 Przykładem dobrze ilustrującym taki produkt mogą być „elektroniczne książki”, np. telefoniczne, które są powszechnie udostępniane w sieci oraz artykuły, zdjęcia, muzyka, filmy oraz wszelkie kategorie oprogramowania i danych udostępnianych w formie elektronicznej - od gier komputerowych, po systemy zarządzania bazami danych. Sieć może być również wykorzystywana do dystrybucji usług doradczych upowszechnianych w postaci tekstu, głosu, czy filmu wideo oraz do prowadzenia szkoleń. 


\section{Internet w przedsiębiorstwie i jego konsekwencje}

Za sprawą internetu dokonuje się wiele znaczących zmian w strukturze wewnętrznej przedsiębiorstwa. Owe zmiany można zaobserwować również w otoczeniu przedsiębiorstwa - przede wszystkim rynkowym, a głównym czynnikiem sprawczym jest właśnie internet. Syntetycznie zagadnienie ujmując, za najbardziej istotne zmiany $\mathrm{w}$ otoczeniu wywołane skutkiem stosowania $\mathrm{w}$ przedsiębiorstwach internetu można uznać:

- redukcję kosztów dystrybucji,

- wzrost znaczenia prawa rosnących dochodów,

- wzrost siły przetargowej klientów (dostawców i odbiorców),

- obniżenie kosztu zmiany dostawcy,

- eliminowanie pośredników,

- rozwój społeczności wirtualnych,

- atomizacja łańcucha wartości polegająca na jego rozbiciu na mniejsze ogniwa.

Możliwości redukowania kosztów dystrybucji ujawniają się wszędzie tam, gdzie produkty mają czysto fizyczny charakter, przy czym odległość klienta od centrum dystrybucji nie odgrywa tutaj większego znaczenia, bowiem głównym źródłem obniżki kosztów jest prowadzenie sprzedaży (przyjmowanie zamówień i obsługa płatności) przez sieć internet. Pozwala to na unikanie ponoszonych kosztów dystrybucji, które $\mathrm{w}$ tradycyjnym handlu wiążą się z tworzeniem łańcuchów, zwanych łańcuchami dystrybucyjnymi oraz sieci sprzedaży detalicznej, co normalnie wymaga ponoszenia kosztów ich utrzymania (budowa, wynajem, eksploatacja, koszty osobowe, itd.).

Internet prowadzi również do utrwalania się znaczenia prawa rosnących dochodów. Wynikiem to między innymi z przechodzenia gospodarki od produkcji opartej na wykorzystaniu surowców, do gospodarki wiedzy, w której znaczenie zyskuje znajomość technologii związanej z przetwarzaniem informacji i umiejętność wykorzystywania ultranowoczesnych źródeł zasobów przydatnych w procesie wytwórczym.

\section{Internet a łańcuch wartości przedsiębiorstwa}

W rozważaniach na temat instrumentów służących polepszaniu działań sprzyjających współczesnemu przedsiębiorstwu poszukiwanie sposobów na budowanie przewagi konkurencyjnej, nie sposób nie odnieść się do zagadnień związanych z łańcuchem wartości przedsiębiorstwa. Należy zatem przybliżyć niektóre - zdaniem autora ważne jego aspekty praktyczne, wynikające z możliwości, jakie ujawniają się wskutek implementowania w przedsiębiorstwie technologii elektronicznych - internetu oraz jego odmian. Stąd, w dalszej części artykułu skoncentrowano się na praktycznej ocenie wyko- 
rzystywania sieci internet i jej wpływu na obniżkę kosztów działalności oraz znaczeniu tego narzędzia dla poprawiania konkurencyjności przedsiębiorstwa. Omówiono więc technologie internetowe wykorzystywane w odniesieniu do łańcucha wartości, a z uwagi na jego znaczenie dla analizy potencjału przedsiębiorstwa rozważaniom zostaną poddane poszczególne jego składowe (ogniwa):

Logistyka wewnętrzna - składają się na nią czynności związane z pozyskiwaniem, przechowywaniem i rozdysponowywaniem środków produkcji i wiąże się ona z dostawami, magazynowaniem i kontrolą zapasów oraz obsługą ewentualnych zwrotów dostawcom. Stosowanie internetu w odniesieniu do logistyki wewnętrznej koncentruje się głównie na działaniach związanych ze wspomaganiem polityki cen zamówień. Przedsiębiorstwo może szybko i po niskim koszcie zebrać aktualne informacje o cenach oferowanych przez dostawców. Może to czynić na różne sposoby, to jest za pomocą wyszukiwarek, które pozwalają na przeglądanie stron WWW wybranych oferentów (dostawców), jak również gromadzić oferty na żądanie, to znaczy w ten sposób, że dostawcy przedkładają przedsiębiorstwu swoje oferty bezpośrednio z wykorzystaniem sieci. Sieć ze swoimi możliwościami wydaje się szczególnie atrakcyjna dla małych i średnich przedsiębiorstw o ambicjach ponadlokalnych, zwłaszcza z uwagi na niski koszt jej posiadania i użytkowania. Mogą one łatwo wyszukiwać w sieci potencjalnych partnerów oraz klientów i gromadzić wszelkie informacje o nich, co bez internetu byłoby obwarowane wieloma trudnościami - koniecznością dysponowania specjalnymi służbami i angażowania „wywiadowni gospodarczych”, uczestnictwem w targach i konferencjach oraz prowadzenia licznej korespondencji (często długotrwałej i nie przynoszącej efektów). W przypadku składania zamówień korzystanie z sieci internet wydaje się szczególnie atrakcyjne z uwagi na sprawność zawierania transakcji. Zamówienia są składane bezpośrednio (za pośrednictwem sieci), czynności związane z zamawianiem minimalizują więc czas i koszty, które normalnie trzeba ponosić w kontaktach z klientami, a równocześnie - wykorzystując do potrzeb wewnętrznej komunikacji i informacji intranet - możliwe jest zapewnienie lepszej koordynacji i kontroli obiegu dokumentów związanych z realizacją składanych zamówień.

Procesy produkcji - internet tworzy w tym obszarze znaczne możliwości wynikające, między innymi, z szybkiego dostępu do informacji o działalności przedsiębiorstwa i przebiegu procesu produkcji, a jego otwartość otwiera również możliwości włączania się klienta (nabywcy) do procesu kontroli wytwarzanych (zamówionych) produktów. Podkreślano wielokrotnie, że sieć internet gwarantuje szybką transmisje danych po niewielkich kosztach. Stąd, przedsiębiorstwa doceniając znaczenie tych atrybutów dla funkcjonowania na globalnym rynku, sięgają po internet z zamiarem polepszania koordynacji działań objętych procesem produkcji. Korzystają z niego również banki oraz przedsiębiorstwa zajmujące się konsultingiem, dla których szybki dostęp do informacji oraz możliwość lepszej koordynacji w różnych obszarach aktywności, jest kluczowym czynnikiem sukcesu. Dzięki wykorzystaniu intranetu moż- 
liwe staje się uelastycznianie systemów pracy. Menedżerowie chętnie sięgają po internet licząc na obniżenie kosztów związanych z procesami produkcji, a równocześnie na wzrost satysfakcji pracowników, co może się przekładać na ich wyższą produktywność.

Logistyka zewnętrzna - ogniwo to odnosi się do czynności związanych z dostarczaniem finalnego produktu do klienta i w tym obszarze internet znajduje szerokie zastosowanie z racji możliwości bezpośredniego dostępu do klienta. Przedsiębiorstwo, dostrzegając $\mathrm{w}$ internecie kolejną szansę na obniżanie kosztów dystrybucji, wykazuje skłonność do konsekwentnego skracania łańcuchów dystrybucyjnych, eliminując w ten sposób pośredników, a równocześnie ujawnia się zjawisko i rośnie rola, tzw. organizatorów społeczności wirtualnych, których głównym zadaniem jest dbałość o właściwe relacje między tymi społecznościami a sprzedawcami (producentami). Wskutek wykorzystania jego zdolności do transmisji produktu, internet znacznie redukuje koszty dystrybucji, zwiększa szybkość dostaw i wzmacnia satysfakcję klientów. Odnosi się to wyłącznie do takich przypadków, gdy do przekazu danego produktu czy usługi można wykorzystać drogę elektroniczną. Do kategorii takich produktów i usług można włączyć, między innymi, usługi bankowe, które powszechnie uwzględniają usługę elektronicznych czeków, opłat rachunków, załatwianie operacji finansowych (przelewów) oraz zarządzanie kontem za pośrednictwem sieci.

Marketing i sprzedaż - polem wykorzystania praktycznych możliwości internetu związanych $\mathrm{z}$ tworzeniem kanałów dystrybucji oraz prowadzeniem działań reklamowych i promocyjnych jest w łańcuchu wartości ogniwo marketingu i sprzedaży. Podstawowa aktywność, gdzie ujawniają się możliwości internetu to obsługa zamówień, które $\mathrm{w}$ przedsiębiorstwie mogą być przyjmowane bezpośrednio przez sieć. Tym samym, nie angażując zasobów na bardziej precyzyjne identyfikowanie odbiorcy reklamy i jego potrzeb ludzkich i technicznych, przedsiębiorstwo uzyskuje obniżkę kosztów transakcji i tworzy możliwości do przyjmowania i obsługi większej liczby zamówień oraz szansę na skrócenie czasu ich obsługi.

Organizacja sposobu składania zamówień na ogół wymaga wejścia na stronę WWW danego przedsiębiorstwa, wybrania produktu (usługi), wypełnienia formularza danych, sprecyzowania sposobu zapłaty oraz - w przypadku zapłaty kartą kredytową - podania jej numeru. Postępowanie kończy wciśnięcie odpowiedniego przycisku klawiatury komputera celem potwierdzenia ustaleń transakcji i transmisji danych. $\mathrm{W}$ przypadku przedsiębiorstw $\mathrm{i}$ ich wzajemnych relacji, dokonywanie transakcji w sieci może być rozszerzone o system elektronicznej wymiany dokumentów EDI, co umożliwia szybkie i niezawodne dwukierunkowe przesyłanie dokumentów finansowych (faktur, poleceń przelewu, dokumentów magazynowych, rachunków, itd.).

Istotą pozyskiwania przyszłych klientów jest wywołanie ich zainteresowania stronami WWW przedsiębiorstwa, gdzie mogą oni odnaleźć ważne dla nich informacje, które skłonią ich do zwiększonego zainteresowania produktem czy usługą, przedsiębiorstwem i jego ofertą, ceną i warunkami dostawy, obsługą po sprzedaży (serwi- 
sem). Szacuje się, że sprzedaż internetowa będzie rozwijać się, a sprzyjać temu będą - z jednej strony presja rynku i korzyści z tytułu wartości dodanej oferowanej klientom, z drugiej zaś - oczekiwania przedsiębiorców (sprzedawców), dla których internet tworzy możliwości docierania do homogenicznej grupy docelowej w ramach tworzących się społeczności wirtualnych. Sieć internet jest więc skutecznym instrumentem wspierania sprzedaży, głównie przez wykorzystywanie go w działaniach reklamowych przedsiębiorstwa.

Wspomniano już, że korzystanie z reklamy i promocji w sieci internet, mimo rosnącego uznania, wciąż nie jest tak powszechne, jak dzieje się to w przypadku pozostałych mediów. Niemniej, o atrakcyjności internetu świadczą wszak inne, istotne dla rozwoju tej formy wzmacniania łańcucha wartości - cechy. Okazuje się bowiem, że internet umożliwia także lepszą ocenę skuteczności reklamy niż dzieje się to w innych mediach, a ponadto, pozwala na bardziej precyzyjne identyfikowanie odbiorcy reklamy i jego potrzeb, ludzkich i technicznych, przedsiębiorstwo uzyskuje obniżkę kosztów transakcji i tworzy możliwości do przyjmowania i obsługi większej liczby zamówień oraz szansę na skrócenie czasu ich obsługi.

Przedsiębiorstwa przez tworzenie stron WWW zyskują również możliwość zaistnienia na globalnym rynku. O popularności stron WWW przesądza zdecydowanie niski koszt zbudowania i utrzymywania ich wobec możliwych korzyści, wynikających z liczby potencjalnych klientów, do których przedsiębiorstwo uzyskuje dostęp.

Wykorzystując sieć internet przedsiębiorstwo zyskuje możliwość tworzenia i rozwijania zasobów wiedzy, które gromadzą ogromne ilości informacji o rynku i jego klientach. Za pomocą specjalnych kwerend, może ono pozyskiwać, gromadzić i sortować takie informacje, korzystając przy tym ze specjalnego oprogramowania i urządzeń, których produkcją i rozwojem zajmują się wyspecjalizowane firmy.

Łatwy dostęp do informacji związanych z produktami i usługami konkurentów umożliwia bieżące monitorowanie ich posunięć i antycypowanie zamiarów, na przykład w zakresie polityki cen akcji reklamowych oraz zapoznawanie się z informacjami na dotyczącymi rozwoju produktów, ich konfiguracji i parametrów, a możliwość śledzenia wszystkich przez wszystkich sprawia, że na rynku pojawiły się przedsiębiorstwa świadczące usługi informacyjne ${ }^{5}$.

Serwis - to działania związane z dostarczaniem nabywcy usług, których zamiarem jest zachowanie wartości produktu. Obejmują one takie przykładowe czynności, jak: instruowanie i szkolenie, dostawa i instalacja części zamiennych, czy też naprawa i dostosowywanie produktu do wymagań klienta.

${ }^{5}$ W Europie w tym sektorze pracuje już ponad $12 \%$ ogółu zatrudnionych, a w ciągu najbliższych trzech lat, ich liczba zwiększy się o 1/3. Również w Polsce działa na tym rynku kilkadziesiąt przedsiębiorstw, których roczne przychody sięgają $200 \mathrm{mln}$ zł. Analitycy szacują, że za sprawą szybko rozwijających się technologii umożliwiających docieranie do setek tysięcy klientów, rynek tych usług będzie rosnąć w tempie $20 \%$ rocznie. 
Korzystając z sieci internet przedsiębiorstwo ma możliwości indywidualnego kontaktu z klientami. Dzięki temu może ono szybciej, a przede wszystkim właściwiej reagować na ich potrzeby, a to oznacza, że potrafi je lepiej zaspokajać, a tym samym zdobywać ich lojalność i zaufanie. Przedsiębiorstwa czynią to na wiele sposobów, na przykład, wiele z nich oferuje internetowy serwis całodobowy i całotygodniowy. Inne, budując lojalność klientów, organizują, tzw. fora dyskusyjne użytkowników, umożliwiając klientom wymianę poglądów i uwag, a najczęściej poruszane kwestie i odpowiedzi na nie, zamieszczane są na specjalnej stronie WWW. Rozwiązanie to jest obowiązującą usługą w przypadku wielu branż, na przykład, producentów oprogramowania, samochodów, komputerów i usług finansowych.

Przedsiębiorstwa oferujące w sieci internet produkty wymagające od nabywcy większego doświadczenia bądź konsultacji z ich przedstawicielem, umieszczają dodatkowo na swoich stronach WWW krótkie kursy mające na celu wzbogacenie jego wiedzy w tym zakresie. Zamiarem takich zabiegów jest wyeliminowanie kosztów serwisu, dojazdów do klienta i kosztów wynikających z rozmów telefonicznych z klientami, które składają się per saldo na niższe koszty obsługi gwarancyjnej.

Infrastruktura przedsiębiorstwa - przypomnijmy, że tworzą ją zróżnicowane obszary aktywności przedsiębiorstwa, to jest: administrowanie, planowanie, finanse i rachunkowość, obsługa prawna oraz działania, których celem jest zapewnienie jakości produkowanych wyrobów i świadczonych usług. Działania te mają charakter wspierający łańcuch wartości, przy czym kluczowego znaczenia w ich implementacji odgrywa kultura organizacyjna i umiejętności związane z zarządzaniem wiedzą.

Sieć internet wzmacnia efektywność tego ogniwa łańcucha wartości, a równocześnie jest czynnikiem strukturotwórczym w tworzeniu i eksploatacji wiedzy, a poprzez wypełnianie ról informacyjnych i komunikacyjnych, staje się ważnym instrumentem w formowaniu kultury organizacyjnej przedsiębiorstwa. Wykorzystując sieć internet, przedsiębiorstwo może silniej wnikać w umysły pracowników oraz kształtować ich zachowania i postawy, a utrwalając wśród pracowników zwyczaje, symbole i wartości oraz sposoby i intensywność komunikacji - kształtować swoją kulturę organizacyjną. Gdy wszyscy pracownicy mają dostęp do sieci można przypuszczać, że łatwiej będą integrować się wokół misji przedsiębiorstwa oraz identyfikować z jego celami.

Internet (wraz z intranetem i extranetem) odgrywa również niebagatelną rolę w pozyskiwaniu i dyfuzji wiedzy przez pracowników przedsiębiorstwa, otwiera bowiem szeroki dostęp do wiedzy użytecznej (praktycznej) dla wielu różnych obszarów jego działalności. Może to skutkować wyższą efektywnością pracowników i innowacjami w odniesieniu do produkcji, a które są wynikiem krzywej doświadczenia. W praktyce organizacyjnej przedsiębiorstw wzmaga to potrzebę tworzenia zasobów wiedzy oraz korzystania z szans, jakie one tworzą do sprawniejszego zarządzania obszarem infrastruktury przedsiębiorstwa. 
Sieć internet tworzy również możliwości poprawy jakości komunikacji wewnętrznej - zwiększa jej intensywność, ale również, jako wynik bezpośrednich połączeń w czasie rzeczywistym, zapewnia terminowość i wiarygodność przekazu. Internet sprawia, że wszyscy użytkownicy sieci wewnątrz i na zewnątrz przedsiębiorstwa mają zapewniony dostęp do sieci w trybie natychmiastowym oraz tworzy możliwości do multilateralnej eksploracji zasobów wiedzy.

Zarządzanie zasobami ludzkimi - w łańcuchu wartości zarządzanie zasobami ludzkimi jest ogniwem wiążącym funkcje personalną przedsiębiorstwa. W tym obszarze internet może być wykorzystywany w sposób zróżnicowany, zależnie od potrzeb w różnych aspektach zarządzania zasobami ludzkimi. Standardowym działaniem staje się umieszczanie na stronach WWW przedsiębiorstwa informacji odnoszących się do rozwoju zawodowego pracowników. Można tam znaleźć wiedzę o polityce zatrudnienia w przedsiębiorstwie, przebiegu ścieżki kariery pracowników oraz informacje związane z formami i zasadami ich wynagradzania na różnych stanowiskach.

Obserwacja praktyki skłania do wniosku, że niemal wszystkie światowe przedsiębiorstwa umieszczają na stronach WWW takie informacje, traktując je jako ważny instrument promocji. Korzystając z sieci internet przedsiębiorstwo może ogłaszać się w sieci w sprawach naboru pracowników, wykorzystując zamieszczane tam inseraty jako uzupełnienie ogłoszeń zamieszczanych w tradycyjnych mediach. Przedsiębiorstwo może korzystać również ze stron WWW agencji zajmujących się pośrednictwem pracy na lokalną, ale również globalną skalę. Agencje takie również posiłkują się zbieraniem aplikacji bezpośrednio poprzez sieć, wykorzystując do tego specjalne formularze elektroniczne, które są następnie przekazywane do przedsiębiorstw zainteresowanych prowadzeniem rekrutacji.

O atrakcyjności tej formy tworzenia rynku pracy przesadza, jak się wydaje, perspektywa korzyści finansowych, jakie niesie ze sobą stosowanie internetu. Zestawiając bowiem szacunkowe oszczędności finansowe możliwe do osiągania przy rekrutacji wspieranej siecią internet $\mathrm{z}$ innymi formami działań z użyciem procedur tradycyjnych, wyraźnie widać, że w warunkach krajów zachodnioeuropejskich ta forma jest zdecydowanie konkurencyjna.

Sieć internet umożliwia również szybszą orientację w problemach przedsiębiorstwa i zasadach jego organizacji, dotyczy to zwłaszcza pracowników nowo przyjętych, którzy mają bezpośredni dostęp do głównych i rozproszonych baz danych, a tym samym mogą uzyskiwać informacje o historii przedsiębiorstwa, jego działalności i typowych problemach, systemie organizacji pracy i obsługiwanych rynkach, zasadach współpracy i kontaktach z kooperantami. Wszystko to powoduje, że informacja szybciej dociera do zainteresowanych, komunikacja jest efektywna, a to może przekładać się na efekty funkcjonowania przedsiębiorstwa jako całości.

Badanie i rozwój - zależnie od przyjętej strategii wszystkie ogniwa łańcucha wartości bądź wybrane jego elementy podlegają wzmocnieniu z użyciem opracowanych w przedsiębiorstwie lub zdobytych na zewnątrz, nowych technologii. Intranet 
powoduje, że możliwa jest szybsza i tańsza wymiana wiedzy, a użyteczne w tym procesie są: poczta elektroniczna, strony WWW, bazy danych oraz dostęp do zasobów znajdujących się w sieci internet.

Dzięki sieci możliwa jest współpraca ze specjalistami, zarówno wewnątrz przedsiębiorstwa, jaki i tymi, którzy pracują w innych oddziałach przedsiębiorstwa macierzystego i przedsiębiorstwach obcych, nawet w odległych krajach. Ta cecha jest szczególnie ważna w projektach międzynarodowych, nad którymi wymaga się pracy ciągłej i skoordynowanej. Pozwala bowiem na nieprzerwaną pracę nad tym samym projektem, przy zmieniających się zespołach i zapewnieniu dostępu do tych samych zasobów informacji oraz możliwości monitorowania postępu prac i oceny ich wyników.

Internet tworzy również możliwości łatwiejszej koordynacji łańcucha dostaw (supply chain) w tych przypadkach, gdy przedsiębiorstwo tworzy układy partnerskie ze swoimi kooperantami - dostawcami i odbiorcami. Wybór sposobu rozwiązywania problemów koordynacyjnych jest podyktowany poszukiwaniem niższych kosztów.

Zaopatrzenie - $w$ ramach zaopatrzenia dokonuje się zakupów środków produkcji, które następnie używane są w łańcuchu wartości przedsiębiorstwa. Procesy zaopatrzeniowe można silniej scentralizować a równocześnie lepiej skoordynować, wykorzystując w tym celu intranet oraz internet oraz ich możliwości, głównym celem tego zamierzenia jest dążenie do obniżki kosztów transakcji. Obydwa narzędzia nabierają $\mathrm{w}$ tym ogniwie kapitalnego znaczenia, z uwagi na to, że pojęcie zaopatrzenia jest terminem znacznie obszerniejszym, niż termin zakupy, a to powoduje, że możliwości aplikacyjne intranetu i internetu znacznie rosną, znajdując więcej okazji do wspomagania tego ogniwa.

Konkludując, trzeba podkreślić, że w poszukiwaniu sposobów optymalizacji łańcucha wartości przedsiębiorstwa, internet pełni ważną rolę, zarówno w odniesieniu do jego ogniw, jak i łańcucha wartości jako całości, jak również poprawia funkcjonowania przedsiębiorstwa i przyczynia się on do budowania jego przewagi konkurencyjnej.

\section{Podsumowanie}

Założenie, że sieć internet jest narzędziem wzajemnej i sprawnej komunikacji przedsiębiorstw, cyberprzestrzenią, w której dokonuje się rozmaitych transakcji związanych wirtualną wymianą oraz dystrybucją dóbr i usług, wydaje się twierdzeniem ze wszech miar oczywistym. Należy przy tym uzupełnić, że jest to instrument, z którego powszechnie korzystają przedsiębiorstwa, których naczelnym zamiarem jest uzyskanie trwałej przewagi konkurencyjnej.

Praktyka pokazuje, że tak nakreślony obraz oddaje prawdę rzeczywistości organizacyjnej. Wprawdzie internet jako innowacja technologiczna jest łatwy do skopiowania - stąd jego powszechność i dostęp do niego, który leży w zasięgu każdego przedsiębior- 
stwa - lecz równocześnie każdy z podmiotów walczących o przywództwo na rynku ma możliwość wykonania tzw. pierwszego posunięcia, co oznacza, że może być szybszy i sprawniejszy w jego stosowaniu, jak również - przedsiębiorstwo samo może wyznaczać margines swobody w kształtowaniu źródeł pozwalających na odróżnianie się z korzyścią dla niego na rynku ${ }^{6}$.

Istotą przewagi wynikającej z pierwszego posunięcia jest rola czasu - szybkość działania przy równoczesnym wykorzystaniu źródeł przewagi konkurencyjnej, na przykład, poszukiwanie niższych kosztów, lepszego wykorzystania zasobów, doskonalsze kompetencje. Przedsiębiorstwo, które jako pierwsze wykona ruch na rynku ma szansę określania zasad gry rynkowej, które może narzucić konkurentom. Wykorzystując przy tym sieć internet możliwe staje się:

1. Upowszechnianie standardów, bardziej odpowiadających potencjałowi przedsiębiorstwa i zgodnych z konfiguracją jego zasobów, niźli tym samym czynnikom u konkurencji.

2. Budowanie lojalności klientów, a następnie tworzenie barier wyjścia przez zwiększenie kosztów zmiany dostawcy ${ }^{7}$.

3. Tworzenie stabilnych relacji z najlepszymi z najlepszych dostawcami dostępu do sieci, formułując przy tym bariery wejścia dla konkurentów ${ }^{8}$.

4. Rozbudowywanie kompetencji jako wynik krzywej doświadczenia. Dzięki temu, przedsiębiorstwo może oferować bardziej innowacyjne produkty i usługi, co przekłada się na konkurencyjne, bo niższe koszty.

5. Ustalenie wyższych cen niż wynikałoby to z kalkulacji jako rezultat przywileju bycia pierwszym na rynku i wzmacnianie swojej pozycji (finansowej) wobec spóźnionych konkurentów.

6. Skupianie na sobie uwagi mediów, a przez to skuteczne upowszechnianie wizerunku przedsiębiorstwa - bycie pierwszym na rynku oznacza w tym przypadku większe zainteresowanie mediów nowościami (innowacjami i nowymi technologiami).

${ }^{6}$ Ponieważ sieć internet jest technologią powszechnie dostępną, więc konkurenci i rywale nie mają żadnych trudności, aby skopiować rozwiązania innowacyjne innych uczestników rynku. Jeżeli, np. przedsiębiorstwo (lider na rynku) rozpocznie sprzedaż produktów w sieci, to jego konkurent może zrobić dokładnie to samo. Kopiując ten sam model działalności i funkcjonując na identycznych zasadach, możliwe jest osiąganie przez niego podobnych korzyści i przez to, niwelowanie przewagi przedsiębiorstwa (lidera). Przedsiębiorstwu (liderowi) pozostaje zatem do rozważenia możliwość osiągania przewagi wskutek wykonania pierwszego posunięcia, ewentualnie, serii posunięć obliczonych na odróżnianie się na tle pozostałych uczestników rynku.

${ }^{7}$ Można tego dokonać dostarczając klientowi wartości wyższej niż mogą to uczynić konkurenci, np. przez zwiększoną liczbę informacji o produkcie, narzucając mu przy tym rozwiązania techniczne o określonych standardach, nieznanych konkurentom.

8 Mogą temu służyć umowy z dostawcami usług informatycznych, którzy przodują na rynku, dysponując najlepszej jakości połączeniami, przepustowością, bezpieczeństwem przekazu, itp. 
7. Tworzenie warunków do elastycznego działania przedsiębiorstwa, dostosowywanie rozwiązań w obrębie jego łańcucha wartości i łatwiejszy dostęp do źródeł przewagi konkurencyjnej.

8. Kreowanie rozwiązań innowacyjnych $\mathrm{i}$ przywilej korzystania $\mathrm{z}$ prawa rosnących dochodów oraz zdominowanie rynku, z równoczesnym tworzeniem społeczności wirtualnych bądź budowaniem korzystnych z nimi relacji.

9. Tworzenie warunków (możliwości) precyzowania konkurencyjnych, atrakcyjnych cen i pełniejszego zaspokajania potrzeb klientów jako skutek lepszej identyfikacji ich wymagań oraz informacji o powiązaniach konkurencji.

10. Budowanie przestrzeni rynkowej (poszerzanie rynków) jako wynik zwiększonego popytu i podaży, wskutek czego zwiększa się produkcja z równoczesną stabilizacją cenową.

Formułując refleksje końcowe trzeba wyraźnie podkreślić, że internet ma kluczowy wpływ na funkcjonowanie współczesnego przedsiębiorstwa i będzie determinować jego działalność także w dającej się przewidzieć przyszłości. Wskazują na to zarówno teoretyczne koncepcje rozważane w literaturze przedmiotu, jak i wnioski płynące z obserwacji praktyki. Niezależnie więc od mogących się ujawniać zagrożeń, takich jak problem bezpieczeństwa danych i kontroli sieci oraz prac nad rozwijaniem nowych technologii, na przykład prace nad wykorzystaniem sieci teleenergetycznych do transmisji danych, można przyjąć, że internet będzie nadal czynnikiem dynamizującym rozwój elektronicznego biznesu.

\section{Bibliografia}

Cairncross, F. (1997). The Death of Distance. Boston: Harvard Business Press.

Kaku, M. (2000). Wizje, czyli jak nauka zmieni świat w XXI wieku. Warszawa: Wydawnictwo Prószyński i S-ka.

Keen, P., Balance, C., Chan, S., Schrump, S. (1999). Electronic Commerce Relationships. Trust by Design. New York: Prentice Hall Edition.

Szapiro, T., Ciemniak, R. (1999). Internet - nowa strategia firmy. Warszawa: Wydawnictwo Difin. 


\section{IT TECHNOLOGIESAND THEIR SERVISE'S ROLE IN THE ENTERPRISE OF GLOBALIZATION AGE}

Keywords: network, enterprise of globalization age, IT technologies

Summary. The paper presents a briefly given challenges faced by enterprises of the age of globalization, and ways of mitigating them including information and communication technologies (IT). Ways of solving problems are discussed, taking into consideration activities of enterprises regarding to all links of the value chain.

Translated by Zbigniew Malara

\section{Cytowanie}

Malara, Z. (2017). Technologie IT na usługach przedsiębiorstwa wieku globalizacji. Ekonomiczne Problemy Ustug, 1 (126/1), 187-201. DOI: 10.18276/epu.2017.126/1-20. 